\title{
AUDIT FEE ECONOMETRICAL MODELS AN OVERVIEW OF THE AUDITING RESEARCH LITERATURE
}

\author{
Ivan P. Oana Raluca ${ }^{l}$
}

\begin{abstract}
Our research intends to present a literature review on studies regarding the audit fee and its cost behavioral in relation to the audit process. The purpose of the paper is to enhance and synthesize the main results of auditing research literature impending audit fee approximation. Hence, our analysis requires a literature review methodology. We start by introducing the concept of audit fee; the first part of the paper follows the shift taking place in the cost behavior of audit in a diachronic study methodology. The main part of the paper discusses empirical studies on audit fee by closely analyzing their research design, the employed research methodology and the obtained results. The originality of the study, its contribution relies in a consisting and comprehensive overview on papers in auditing research literature that presents audit fee through an empirical approach. When in comes to the importance and reliability of such studies further impacts upon the relevance of their results and how they can be used.
\end{abstract}

Key words: audit fee, empirical research, econometric model, research literature

JEL codes: M42, M40

\section{Introduction}

The concept of information asymmetry emerged from the studies of three very important economic researchers (Akerlof, Spence and Stigliz), thus they have made the economic theory evolve establishing the basis for modern economic theory (Riley, 2001). Their work, acknowledged in 2001, by a Nobel Prize was a departing point for Ng's research (1978), which uses the theoretical framework in order to characterize the conceptual paradigm of the financial information asymmetry: the manager is always better informed than the stakeholder. This problem equires control means for the stakeholder, and one of them is identified as, the external audit. $\mathrm{Ng}$ (1978) appreciates that the external auditors have two main functions complementing the reduction of the information asymmetry: they detect the eventual non-compliance to the accounting regulations and limit the discretionary accounting practices of the managers. Relying on this theory, Watts \& Zimmermann (1986) appreciates that an audit is efficient,when an auditor is competent and independent. One of the main characteristics of the auditor's independence is a correct fee for the service.

In this research we tried to demark a research winning the social impact of the auditing phenomenon quantified through the audit fee, this research is carried on which is performed by steadfast by two main differentiation segment: time and space, thus we consider as well the fruition of the audit fee parameter from the auditing phenomena and its determinants. The study components of the maket at a worldwide-level for the audit services composed in a classic manner from: demand, offer and cost (price) in addition to the two main participants: the auditor and the audited), is primarily targeting another very important component cost - audit fee. We appreciate that this component is the most difficult to calculate and connect with its component.

This paper evaluates research that examines the determinants of audit fees over the past three decades, and investigates changes observed from recently-published studies on its the quantification.

\footnotetext{
1 “1 Decembrie 1918” University of Alba Iulia, Romania,e-mail: raluca.ivan@uab.ro
} 
In what the improvement of the auditor's autonomy is concerned, a reference study mentions that one of the most important trends of research is establishing the theoretical and scientific basis (statistical and mathematical) methods of quantifying the fees proposed by the auditor; independently of their nature, audit fees other non-audit fees.

Throughout the years, there have been a series of fierce debates on the subject of need to disclose the audit fee, and afterwards: to disclose it, but not to reveal the determinants or to whether establish a standard fee or not. In each of the possibilities the economic climate was an undisputed determinant of audit fee behavior and perception.

The conceptual implications of this idea generate a wider opening towards the audit fee paradigm determinants. We identified two breaking points that determine cost behavioral of the audit fee, first of all: Savings and loans crisis (S\&L Crisis) from the U.S.A., during the 80's determined a series of normative actions as the SOX -legislation in the US (2002), followed in the 2006 of the change of the $8^{\text {th }}$ Directive of the EU. We identify the economic crisis from 2008 the second breaking point for the behavioral cost of the audit fee, emerging a not-identified evolution.

Our study is structured as it follows: a diachronic analysis on the evolution of the audit fee and its determinants, based on auditing followed by basis the employed research methodology; preparing the analysis is done together with discussing the obtained results and finally presenting some concluding remarks.

\section{Diachronic analysis of the cost behavioral - audit fee}

The auditing market and its audit fees is a subject studied both in developed (US, Australia, Canada) and emerging economies (Hong Kong, Malaysia, Singapore). However the audit services market in emerging economies has been given limited attention. Hay and colleagues (2006) conducted a meta-study examining possible determinants of the amount of audit fees in the last 25 years (1977-2002). Of the 88 research papers included in their analysis, only 6 were related to auditing activity in emerging market countries, while 45 were related to United State's market. Hay (2006) considered in the mentioned meta-study that audit fees determinants are: customer size, the overall audit risk, and complexity of the client, customer profitability, owners of the company, the degree of competition of market share

As a diachronic approach the period pre- Savings and loans crisis (S\&L Crisis), (so before SOX) the study on the evolution of audit services fees on regulated markets is characterized by no disclosure obligation on the audit fee by the audited nor by the auditor. For the US market only a Standard and Poor survey shows that the audit fees evolved from $0.08 \%$ of turnover in 1975 to $0.1 \%$ of turnover in 2001. Regarding fees post-SOX audit services they are characterized as follows: increased with $292 \%$ for small firms audit, increased $245 \%$ for medium companies, increased by $63 \%$ for top 500 U.S. companies. Also there is an increase from $0.1 \%$ to $0.3 \%$ of turnover.

Empirical studies on audit fees conducted in US and Australia before 2001 (SOX) shows that the audit fee for the first audit mission is significantly lower than the one of a recurrent audit mission. Two important studies from US realized by Francis şi Simon (1988) for the period from 1979-1984, and Ettredge şi Greenberg (1997), for the period from 1985-1995, shows that the audit fee for the first mission are $24 \%$ lower that the audit fee for the following missions.

The practice of setting lower initial audit fees have been the subject of numerous studies because the major impact that could have on the independence of auditors. De Angelo (1981), Chan (1999), and Whisenent, Sankaraguruswamy, Raghunandan (2003) believe that the practice of setting lower initial audit fees is due the following two factors: cost of auditor change, and expectations of the auditor to establish higher fees in the following years. DeAngelo characterize the difference between expected future audit fees and costs of audits as a quasi-rent.

According to Chan's model (1999) it is considered if it prohibits the reduction of initial audit fees would be the immediate effect of the automatically whooping growth of overall audit 
fees. While Morgan and Stöcken's model (1998) considers the auditor's acceptance of all of the difference between the cost of the audit and the fee charged for this first year audit, the model developed by Zhang (1999) concludes: the lowest fees in the first year the audit is basically audit costs, zero profit for their activity. The result of this fight will be based on the auditor's ability to negotiate having the force of quasi-monopoly, and the client who has quasimonophony power. Also consider Zhang's model explicitly for the first time as a factor: the interaction between auditor and client negotiation act and ability level of the client to reduce the auditor's independence.

\section{Research methodology}

The employed research methodology largely relies on literature review particularities. Similar to Ivan (2009), we develop a critical and evaluative account of what has been published within accounting research literature on audit fee, but while only considering studies that develop an empirical approach and a statistical/econometrical model. Therefore, in accordance to literature review methodology imposed each considered study to be analyzed by looking at particular elements such as: study hypothesis, determinants token into consideration, qualitative factors token into consideration, econometrical model obtained as result. Summary and synthesis is used to discuss the principal and secondary results obtained through the analyzed researches.

\section{Presenting the analysis and discussing the obtained results}

The relation established between the audit quality and the audit fee has made a study subject for several researchers. So for the audit services from the United States of America, there is an empirical database that consists of a number of important studies comprising 231980 to 2000 to support the idea that really big international auditing companies (Big4) made audits of higher quality than the other (DeAngelo(1981)). Another study Che-Ahmad \&Houghton (1996) reveals that Big 4 firms arrives to a court trail less often and are less sanctioned by regulatory bodies (SEC, in this case), both arguments suggesting a much higher success rate of the audit.

Using a geographical delineation we can identify several countries with a good representation for these studies. In the US the problematic of audit fee and the its influencing factors was analyzed since 1980 by D. Simunic to develop a theory of market pricing audit support his theory bringing in a series of convincing evidence. Z. Palmrosemade (1986) published a study on the relationship between auditor fees and audited size and Francis J. and D. Simon in 1987 conducted a test audit pricing in small-customer segment of the market for audit services of the United States.

In the same period in Australia is published a study by J Francis (1984), regarding the auditor size effect on the price of audit services, and with D. Stokes, J. Francis continued his studies in the same direction and published in 1986, empirical studies based on the Australian market for audit services establishing a correlation between audit fees and their fields of activity of the audited entity.

In Britain, P. Chan and collaborators published in 1994, a study revealing the most important components of audit fees for audits of listed companies in the United Kingdom, and Brinn, Peel and Roberts continued the studies of their predecessors and walk through an exploratory study in 1994 presenting the most important components of audit fees for larger entities not traded and independent entities in the UK.

An important place in literature is allocated to country analysis, market audit services and audit fees. In India, D. Simon published together with a team of collaborators an empirical study in 1986 on the market for audit services and audit fees of India. Similar studies were conducted for Hong Kong, Malaysia, and Singapore by L. Low and colleagues, who published in 1990, an analysis of the elements determining the audit fees for audit services, and D. Simon with collaborators, published in 1992, a comparative study between audit services 
markets of the three countries. In New Zealand, M. Firth published in 1984 an analysis of audit fees and their determination methods and in Canada, Chung and Lindsay in 1988 conducted a study on audit market prices, the Canadian perspective and Anderson and Zéghal published in 1994, studies on audit fees from Canadian audit market.

For Japan despite functional economy experienced an economic boom being investigated as such, though exceptionally there aren't any studies in this area earlier than 1997, when Professor Taylor has published a study of audit services market in Japan. In the same year in Pakistan Professors Simon D. and Taylor conducted a survey of audit services in the country, expanding its research and on South Korea in 1999.

For the EU audit market space we do not have many studies related to this issue in France Gonthier-Besacier, N., Schatt A. (2007)establish the determinants of audit fees for French quoted firms. Also the particularities of the audit market, where two (joint) auditors are required by law creates a unique setting to study if a firm's ownership structure affects its auditor-pair choice as well the consequences on earning quality Francis, Richard Vanstraelen (2009)

in Romania Pop At., Iosivan R (2008) investigate the evolution of the audit fee for the Romanian market, but just for a part of the country, no industry related parameters, or size.

Research in the development of models to quantify audit fees dating back to the early 80 s, of course they were made on non-regulated markets Sullivan, M. W., (2000),. Starting with the study conducted by Simunic (1980), a great number of researches examined the microeconomic climate for audit services market.

One of the most sophisticated model, is the Carson/Fargher/Simon (2004), developed on the Australian audit market for the period from 1995-1999.

They have built the model trying to capture the individual characteristics of the client by the following some parameters: the size of the entity have used natural logarithm Total Assets; complexity of the audit process is surprised by the number of subsidiaries to the entity, and the percentage of foreign subsidiaries, the audit risk is surprised by the following parameters: current assets / total assets, treasury, long-term debt / total assets, income before tax / total assets, the indicator of opinion (dummy indicator variable with value 1 for a qualified opinion, and zero otherwise) recent loss indicator (dummy with value 1 for a loss in any of the past three years, 0 otherwise) was also used for assessing an indicator showing either to belong or not to the mining industry, an indicator was introduced in a model that illustrates the relationship quantify the complexity of the relationship between auditor and audited is the natural logarithm of auditor services paid (thousand dollars) (this indicator was taken from the model Ezzamel, Gwilliam and Holland (2002)) eventually researchers introduced an (dummy), an indicator for the auditor's being from the former Big 6şi 0 otherwise.

$\ln ($ cuantum $)=\alpha+\beta 1 \ln ($ Total Active $)+\beta 2$ Subs $+\beta 3$ Străine $+\beta 4$ Minier $+\beta 5$ CATA + $\beta 6 Q u i c k+\beta 7$ Leverage $+\beta 8 R O I+\beta 9 O p i n i o n+\beta 10 Y E+\beta 11 L o s s+\beta 12$ In (Other Services) + $\beta 13$ Big $6+\varepsilon[1]$

$\ln ($ cuantum)=audit fee;

Total Active = Total assets;

Subs = Radical complexity of the audit process is surprised by the number of subsidiaries to the entity;

Străine = percentage of foreign subsidiaries;

Minier = dummy indicator variable with value 1 for a being in the mining industry, and zero otherwise;

Quick = trezoreria;

Leverage $=$ datorii pe termen lung/total active;

ROI= Return on investmnt ;

Opinion = dummy indicator variable with value 1 for a qualified opinion, and zero otherwise;

$\mathrm{YE}=$ dummy indicator variable with value 1 for a the fiscal year that does not end on the 1 
June, and zero otherwise

LOSS = dummy indicator variable with value 1 for a any loss within the last three years, and zero otherwise

Other Services $=$ natural logarithm for any other services paid to the auditor (thousand dollars)

Big $6=$ dummy indicator variable with value 1 for a the auditor being in the BIG 4, and zero otherwise;

A second very interesting model is the one developed by Mitra S., Hossain M., Deis R (2007) on the US audit market tries to quantify the audit fee in relation to the property characteristics of the entity's. In the first phase of the study they investigated empirical relationship between ownership characteristics of the entity and the amount of fees. The starting point was that: the level of sophistication and the extent to which property ownership is complex, in terms of number of large owners has a substantial impact in monitoring the business entity, including the financial reporting process. Next they studied the connection between the distance from bottom to top management, the effect on interpretations and ultimately financial reporting performed randomly.

They used a selection of 358 entities listed on the New York, audited by a companies belonging to the Big 5, and the hypotheses confirmed were: there is a direct relationship of dependence between institutional share owners and audit fee but not of great importance (less 5\%), and a negative significant relationship between the important owners of shares, (over 5\%) and the audit of fees. Furthermore it has been shown that the ownership of shares by top management is negatively dependent on the audit fees, but there was no possibility to establish a link between individual shareholders with more than $5 \%$ and the audit fees.

We can conclude that in establishing a connection for the audit fee for the U.S. market an important factor is the user's external financial accounting information, so important that it can quantify in a audit fee model We consider that motivation granting such importance should be seen in terms of attracting the auditor's liability in the entity's financial statement.

$\mathrm{LAFEE}=\beta 0+\beta 1 \mathrm{LTA}+\beta 2 \mathrm{SUB}+\beta 3 \mathrm{REC}+\beta 4 \mathrm{INV}+\beta 5 \mathrm{LOSS}+\beta 6 \mathrm{FOROPR}+\beta 7+\beta 8 \mathrm{MB}$ $+\beta 9 \mathrm{LEV}+\beta 10 \mathrm{ROA}+\beta 11 \mathrm{FCF}+\beta 12$ CEOIND + $\beta 13$ BDMT $+\beta 14$ BDEXP + $\beta 15$ BDINDP + $\beta 16$ ACIND + $\beta 17$ ACMEET + $\beta 18$ ACEXP $+\beta 19$ DINST $+\beta 20$ BLOCKINST + $\beta 21$ BLOCKNINST + $\beta 22$ PMGR $+\varepsilon$

Independent:

LAFEE $=$ LN audit fee

Dependent variables to establish companies control:

LTA $=\ln$ of Total Assets ;

SUB $=$ square root of the no of subsidiaries;

REC $=$ Money to be collected $/$ Total Assets

INV = Total Current Assets / Total Assets;

LOSS = dummy indicator variable with value 1 for a any loss within the last three years, and zero otherwise;

FOROPR = Export Sales / Total Assets;

$\mathrm{MB}=$ Current assets / Current liabilities;

LEV = Long term loans / Total Assets;

ROA = Return on Assets;

$\mathrm{FCF}=$ Free Cash Flow;

Dependent variables to establish relation to top-management

$\mathrm{CEOIND}=$ dummy indicator variable with value 1 for the situation of President of the administrative Borad is one and the same with the General Manager, and zero otherwise

BDMT $=$ square roots onthe number of meetings of the Board of Directors;

$\mathrm{BDEXP}=$ Degree of experience of the Administrative Board, square roots from the numbers on the Administrative Board with no managerial position in the company ; 
BDINDP $=$ Procentage of non- specialists in the Board; Dependent variables to characterize Audit Committee

ACIND $=$ dummy indicator variable with value 1 for Audit Committee with members independent, and zero otherwise

ACMEET $=$ dummy indicator variable with value 1 for Audit Committee who has 4 or meeting a year, and zero otherwise;

ACEXP = dummy indicator variable with value 1 for Audit Committee with at least a member with finance and accounting experience, and zero otherwise;

Dependent variables regarding ownership

DINST $=$ Degree of repartisation of the stocks at an institutional level

BLOCKNINST $=$ Degree of stocks owned by non-institutional persons, whom together have 5\% , or more;

PMGR $=$ Percentage of the stocks owned by top management;

It is relevant for our research to present a third model for the audit fee Higgs J.L and Skantz T.R. (2006) that takes into consideration the earning made and the market's reaction. The research investigates the US market for 2000-2011, on 1331 US companies listed to NYSE. They first tested (on the 5 February 2001- for the first time according to SOX it was mandatory to publish audit fees) the following hypothesis: there is a link between the audit fee and the non-audit fees for the same client, proved positive at an average coefficient

The construction of the model was:

AFi $=\beta 0+\beta_{1}$ NAF $_{i}+\beta_{2}$ TA A $_{i}+\beta_{3}$ SQSEGS $_{i}+\beta_{4}$ SQEMPLS $_{i}+\beta_{5}$ DA $_{i}+\beta_{6}$ LIQ $_{i}+\beta_{7}$ IVREC $_{i}+$ $\beta_{8}$ ROA $_{i}+\beta_{9}$ INITIAL $_{i}+\beta_{10}$ BIG5 $_{i}+\beta_{11}$ FOROPSi $+\beta_{12}$ LOSS $_{i}+\beta_{13}$ GR_SALES $_{i}+$ $\beta_{14}$ VOLATILITY $i+\beta_{15}$ EMP_PLAN $_{i}+\beta_{16}$ BM $_{i}+\beta_{17}$ SDOPS $_{i}+\beta_{18}$ CHGPB $_{i}+\beta_{19}$ RESTATES + $\beta_{20}$ RETURN $_{i}+\beta_{21}$ LAG $_{i}+\beta_{22}{ }_{\text {NEW_FIN }}+\beta_{23}$ INST_PCT $_{i}$

$\mathrm{AF}=$ audit fee (natural lograrithm);

$\mathrm{NAF}=$ non-audit fees (natural lograrithm);

TAi $=$ Total Assets (natural lograrithm);

SQSEGS = square roots from the industrial segments in wich the company activates;

SQEMPLS = square roots from emplyee number;

$\mathrm{DA}=$ Debt / Assets;

LIQ = Current assets / current liabilities

INVREC $=$ Stocks $/$ Total Assets;

ROA = Return on Assets;

INITIAL = dummy indicator variable with value 1 for the first year in the audit process Audit, and zero otherwise;

BIG5 = dummy indicator variable with value 1 for a the auditor being in the BIG 5, and zero otherwise;

FOROPS $=$ dummy indicator variable with value 1 for a currency revenue or expense for the last year, and zero otherwise;

LOSS = dummy indicator variable with value 1 for a any loss within the last three years, and zero otherwise;

GR SALES = Income from sales;

VOLATILITY = the covariance of the market model (stocks evolution in) a period of time 255 days/ to 5 days;

EMP PLAN = dummy indicator variable with value 1 for an existing retirement plan and zero otherwise;

XDOPS = dummy indicator variable with value 1 for an existing retirement plan and zero otherwise;

$\mathrm{CHGPB}=$ if there is any change in the solvency of the company

RETURN = Stocks / Total sales; 
LAG = quantifying the number of days up to the public release of financial statements;

This model is interesting because it captures a series of determinants not found in any other audit fee model, like: VOLATILITY -the covariance of the market model (stocks evolution in) a period of time 255 days/ to 5 days; RESTATE indicator that tries to quantify the relationships of the company with the control bodies, and the last LAG parameter - quantifying the number of days up to the public release of financial statements, trying to surprise the psychological impact on entities.

For Romania we identify the construction of a simpler model Pop At. Iosivan R. (2008) beginning with the test of six parameters, and constructing a functional model just with three parameters:

Amount $=\alpha_{0}+\alpha_{1}$ Total Assets $+\alpha_{2}$ Turnover $+\alpha_{3}$ Number of employees;

Analyzing the most important models we consider important presenting the focal point: all of them are linear regression models; all of the models quantify size through a wide ranged of parameters, most of them quantify qualitative factors through dummy variable. All models encountered in practice are linear models for assessing the audit fees, regardless of the form in which it has logarithmic or not.

We identify a need for future researches it is necessary a segmental approach of the market, the common rule is a segmental approach of audit services according to the following criteria: both their legal and statutory obligation and denomination as business segment, size of audited entity, and the criterion of geographical delimitation of entity location can also be found.

In our opinion the Qualitative parameters quantifiable by means of dummy variables to be taken into consideration for the future quantification models are as follows: auditor's membership or non-membership of BIG4 , subsidiary auditor's functioning as body corporate or self-employed person, existence of foreign subsidiaries of audited entity, auditor's opinion, whether pertinent or not, existence of a clash of interests at the level of top management (it is possible to have the general manager involved by holding or not holding shares), existence or inexistence of controls to operate significant corrections performed by Inland Revenue Service.

\section{Concluding remarks}

It seems appropriate to conclude on all of these researches conducted in the auditing research literature by highlighting the role they play in the process of establishing the audit fee, the contribution they bring to identifying various aspects those outcomes from the specificities of the audit market in various economies. Researchers concerned with the audit fee establishing process, are authors of unbiased analytical works. While regulating organisms do not a have a saying into this process, there is multiple factor that we must take into consideration that lead to the elaboration of the audit fee. The research activities are the one which provide necessary information for that process and posses the necessary questions that final users of this information needs to address.

\section{References}

1. Anderson T., Zeghal D., 1994. The pricing of Audit Services: Further Evidence from the Canadian Market, Accounting and Business Research Journal, Vol.24, No.95, pp.195-207

2. Carson E., Fargher N., Simon D. T., 2005. Audit fees and market segmentation - further evidence on how client size matters within the context of audit fee models, Journal of Accounting, Auditing and Finance Vol. 17, No. 1, pp. 79-81

3. Chan P., Ezzamel M., Gwilliam D., 1993. Determinants of audit fees for quoted UK companies, Journal of Business Finance and Accounting, Vol. 20, No. 6, pp. 765-786

4. Chan D., 1999. Low-balling and efficiency in a two-period specialization model of auditing competition. Contemporary Accounting Research No.16 pp.609-642 
5. Che-Ahmad A., Houghton K.A., 1996. Audit fee premiums of Big Eight firms: evidence from the market for medium-size UK auditees, International Accounting, Auditing \& Taxation Journal, No. 5, pp. 53-67

6. Choi J.H, Kim J.B., Liu X., Simunic D.A., 2009. Cross-Listing Audit Fee Premiums: Theory and Evidence, The Accounting Review, No.84 (5), pp. 1429-1463

7. Chung D.Y., Lindsay W., 1988. The Pricing of Audit Services: Canadian Perspective, Contemporary Accounting Research, vol. 5, pp. 19-46

8. DeAngelo L.E., 1981. Auditor size and audit quality, Journal of Accounting and Economics, Vol. 3, pp. 183-199

9. Ettredge M.L, Li C., Scholz S., 2007. Audit Fees and Auditor Dismissals in the SarbanesOxley Era, Accounting Horizons, Vol. 21, No. 4, pp. 371-386

10. Ezzamel M., Gwilliam D., Holland K., 2002. The Relationship between Categories of NonAudit Services and Audit Fees: Evidence from the UK', International Journal of Auditing, Vol. 6, No. 1, pp. 13-35

11. Firth M., 1985. An analysis of Audit Fees and their Determinants in New Zealand, A Journal of Practice and Theory, No.2, pp.23-37

12. Francis J. R., Stokes D., Anderson D., 1999. City markets as a unit of analysis in audit research and the re-examination of Big 6 market shares, Abacus, Vol. 35, pp.185-206

13. Francis J. R., 1984. The Effect of Audit Firm Size on Audit Prices: A Study of the Australian Market, Journal of Accounting and Economics, no 6, pp. 133- 151

14. Francis J. R., Simon D.T., 1987. A Test of Audit Pricing in the Small Client Segment of the US Audit Market, Accounting Review, 62, January, pp. 145- 157

15. Francis J. R., Stokes D.T., 1986. Audit Prices, Product differentiation and Scale Economies; Further Evidence from the Australian Market, Journal of Accounting Research, 24(2), Autumn, pp. 383-393

16. Francis J., Richard C., Vanstraelen A., 2009. Assessing France's joint audit requirement: Are two heads better than one?, Auditing: A Journal of Practice and Theory, 28 (2), pp. $35-$ 63

17. Gonthier-Besacier N., Schatt A., 2007. Determinants of audit fees for French quoted firms, Managerial Auditing Journal, No.22, pp. 139-160

18. Hay D. C., Knechel W. R., Wong N., 2006. Audit fees: a meta analysis of the effects of supply and demand attributes, Contemporary Accounting Research Journal, Vol. 23, No. 1, pp.141-191

19. Higgs J.L., Skantz T.R., 2006. Audit and non audit fees and the market's reaction to earnings announcements, Auditing: A Journal of Practice \& Theory, Vol.25, No. 1, pp. 1-26

20. Low L., Tan P., Koh H., 1990. The determination of audit fees: An analysis in the Singapore context, Journal of Business Finance \& Accounting, Vol. 17, pp.285-295

21. Mitra S., Deis R., Hossain M., 2009. The association between audit fees and reported earnings quality in pre- and post-Sarbanes-Oxley regimes, Review of Accounting and Finance, vol. 8, pp. 232-252

22. Mitra S., Hossain M., Deis R., 2007. The empirical relationship between ownership characteristics and audit fees, Review of Quantitative Finance and Accounting, vol. 28. pp. 257-285

23. Morgan J., Stocken P., 1998. The effects of business risk on audit pricing. Review of Accounting Studies No.3 (4), pp.365-385

24. Ng D., 1978. An information economics analysis of financial reporting and external auditing, The Accounting Review, No, 4, pp. 910-920

25. Palmrose Z.-V., 1986a. Audit fees and auditor size : Further evidence, Journal of Accounting Research, Vol. 24, No. 1, pp. 97-110; 
26. Palmrose Z.-V., 1986b. The effects of non-audit services on the pricing of audit services: further evidence, Journal of Accounting Research, No 2, pp. 405-411

27. Palmrose Z.V., 1988. An analysis of auditor litigation and audit service quality, The Accounting Review, 63, pp.55-73

28. Pop At., Iosivan O.R., 2008. The Pricing of Audit Services: Evidence from Romania, Annales Universitatis Apulensis Series Oeconomica, 10, pp. 124-145

29. Riley J., 2001. Silver signals: twenty-five years of screening and signaling, Journal of Economic Literature, no. 39, pp. 432-478

30. Simon D., Taylor M. H., 1997. The market for audit services in Pakistan, Advances in International Accounting, No. 10, pp. 253-261

31. Simunic D., 1980. The pricing of audit services: theory and evidence, Journal of Accounting Research, No. 18, pp.161-190

32. Sullivan M. W., 2000. The effect of big eight accounting firm mergers on the market for audit services, Working paper U.S. Department of Justice, March

33. Taylor M., 1997. The market of Audit services in Japan, Pacific Accounting Review, vol.9, no. 2 , pp.59-74

34. Taylor M. H., Simon D. T., Burton F. G., 1999. A survey of audit pricing in South Korea, Research in Accounting Regulation, Vol. 13, pp. 201-207

35. Watts R. L., Zimmerman J. L., 1986. Positive Accounting Theory, Prentice- Hall Contemporary topics in accounting series

36. Whisenant S., Sankaraguruswamy S., Raghunandan K., 2003. Evidence on the joint determination of audit and non-audit fees. Journal of Accounting Research no. 41, pp. 721744

37. Zhang P., 1999. A bargaining Model of Auditor Reporting, Contemporary Accounting Research, Vol. 16, N0.1R, pp. 167-184

38. Nobelprize 2001. Markets with asymmetric information, Akerlof, Spence et Stiglitz, Nobel Prize, 2001, Http://nobelprize.org/nobel_prizes/economics/laureates/2001/ecoadv.pdf 